\title{
PENGEMBANGAN LEMBAR KERJA SISWA BERBASIS PENDEKATAN CONTEXTUAL TEACHING AND LEARNING BERBANTUAN GEOGEBRA MATERI SEGI EMPAT KELAS VII SMP
}

\author{
Wahyuni Andicha Vassa \\ Universitas Katolik Santo Thomas, Medan; \\ wandichav@gmail.com
}

\begin{abstract}
Abstrak. Penelitian ini bertujuan untuk 1) mengetahui kevaliditan dari penggunaan Lembar Kerja Siswa (LKS) berbasis pendekatan CTL, 2) mengetahui keefektifan dari penggunaan Lembar Kerja Siswa (LKS) berbasis pendekatan CTL sehingga dapat digunakan pada materi Bangun Datar Segiempat kelas VII SMP Swasta GKPI Padang Bulan Medan. Penelitian ini merupakan penelitian pengembangan $(R \mathcal{E} D)$ dengan menggunakan model pengembangan pembelajaran ADDIE dengan tahapan (1) Analysis (Analisis). (2) Design (Perancangan), (3) Develop (Pengembangan), (4) Implement (Implementasi), (5) Evaluation (Evaluasi). Berdasarkan hasil analisis data dan pembahasan diperoleh data hasil validasi ahli dengan rata-rata total penilaian sebesar 4,25 berada pada kategori sangat baik sehingga LKS dikatakan valid dan layak digunakan. Keefektifan LKS berbasis pendekatan CTL dengan bantuan GeoGebra dilihat dari beberapa penilaian yang diperoleh melalui tes hasil belajar yang meliputi : 1) Ketuntasan belajar siswa secara klasikal sebesar $85,18 \%$ berada pada kategori tuntas; (2) Ketercapaian indikator kompetensi dengan persentase sebesar 80.08\% berada pada kategori tuntas; (3) Hasil observasi kemampuan guru mengelola pembelajaran dengan nilai rata-rata 3,72 berada pada kategori sangat baik; (4) Waktu pembelajaran yang efektif selama 4 kali pertempuan; (5) Angket respon siswa terhadap LKS dengan rata-rata penilaian sebesar 5,50 berada pada kategori sangat baik dan setiap aspek direspon positif. Berdasarkan hasil analisis data di atas, dapat disimpulkan bahwa pengembangan Lembar Kerja Siswa (LKS) berbasis pendekatan Contextual Teaching and Learning (CTL) dengan bantuan GeoGebra pada materi Bangun Datar Segiempat kelas VII SMP Swasta GKPI Padang Bulan Medan adalah valid dan efektif yang digunakan dalam menunjang proses pembelajaran matematika.
\end{abstract}

Kata Kunci. Lembar Kerja Siswa, CTL, GeoGebra.

Cartesius: Jurnal Pendidikan Matematika Vol. 2, No. 2

(CProdi Pendidikan Matematika Universitas Katolik Santo Thomas 


\begin{abstract}
This study aims to 1) find out the validity of the use of Student Worksheets (LKS) based on the CTL approach, 2) determine the effectiveness of using Student Worksheets (LKS) based on the CTL approach so that it can be used in the Quadrilateral Build Flat material class VII Padang Bulan GKPI Private Middle School Field. This research is a research development $(R \mathcal{E} D)$ using the ADDIE learning development model with stages (1) Analysis (Analisis), (2) Design (Design), (3) Develop (Development), (4) Implement (Implementation), (5) Evaluation (Evaluation). Based on the results of data analysis and discussion, it was obtained data from expert validation results with an average total rating of 4.25 in the very good category so that the LKS was said to be valid and feasible to use. The effectiveness of the LKS based on the CTL approach with the help of GeoGebra was seen from a number of assessments obtained through learning outcomes tests which included: 1) Classical learning completeness of students at $85.18 \%$ in the complete category; (2) Achievement of competency indicators with a percentage of $80.08 \%$ in the complete category; (3) The results of the observation of the teacher's ability to manage learning with an average value of 3.72 are in the very good category; (4) Effective learning time for four times; (5) Questionnaire of student responses to student worksheets with an average rating of 5.50 is in a very good category and every aspect is responded positively. Based on the results of the above data analysis, it can be concluded that the development of Student Worksheets (LKS) is based on the Contextual Teaching and Learning (CTL) approach with the help of GeoGebra in the quadrangular Build Flat class VII GKPI Private Middle School Padang Bulan Medan is valid and effective used in supporting the process of learning mathematics.
\end{abstract}

Keywords. Student Worksheet, CTL, GeoGebra.

\title{
PENDAHULUAN
}

Pendidikan mempunyai peranan yang sangat penting dalam kehidupan manusia. Pada dasarnya, pendidikan merupakan proses untuk membantu manusia dalam mengembangkan potensi yang dimilikinya sehingga mampu menghadapi perubahan yang terjadi dan dapat menentukan kualitas dalam diri. Oleh sebab itu, pendidikan berperan penting dalam menciptakan sumber daya manusia yang berkualitas, salah satu cirinya adalah dimilikinya kemampuan berpikir kritis. Pendidikan sangat erat kaitannya dengan proses belajar dan pembelajaran. Ini terlihat dari adanya suatu proses pembelajaran. Melalui proses pembelajaran yang berlangsung, seseorang akan mendapatkan pengalaman belajar untuk mencapai suatu tujuan tertentu yang berpengaruh positif bagi pertumbuhan dan perkembangan individu.

Cartesius: Jurnal Pendidikan Matematika Vol. 2, No. 2

CProdi Pendidikan Matematika Universitas Katolik Santo Thomas 
Belajar merupakan suatu bentuk perilaku yang kompleks untuk memperoleh suatu perubahan dari diri seseorang. Kegiatan ini dapat dilakukan sendiri atau juga bersama dengan orang lain. Dalam dunia pendidikan kita mengenal dua subjek penting yang terlibat dalam proses pembelajaran, yakni pendidik dan peserta didik. Guru bertindak sebagai pendidik di sekolah yang akan membelajarkan siswa, sedangkan siswa bertindak sebagai peserta didik yang akan mengikuti pembelajaran dengan guru. Hal ini memberikan makna bahwa terdapat interaksi antara guru dan siswa. Tujuan pendidikan nasional yang tertulis dalam Undang-Undang RI No.20 Tahun 2013 tentang Sistem Pendidikan Nasional adalah meningkatkan kualitas manusia Indonesia, yaitu manusia yang beriman dan bertaqwa kepada Tuhan Yang Maha Esa, berbudi pekerti luhur, berkepribadian mandiri, maju, tangguh, cerdas, kreatif, produktif, serta sehat jasmani dan rohani. Salah satu usaha pemerintah dalam meningkatkan kualitas pendidikan di Indonesia adalah dengan cara memperbaiki kurikulum. Namun fakta yang diperoleh oleh peneliti di lapangan pada saat melaksanakan Observasi Penelitian di sekolah SMP Swasta GKPI Padang Bulan Medan adalah pada proses pembelajaran matematika, dimana guru masih melakukan proses belajarmengajar secara konvensional yang hanya diawali dengan menyajikan materi pembelajaran dengan metode ceramah, memberikan soal dan meminta siswa untuk mengerjakannya terlebih dahulu sebelum dibahas.

Metode ini sangat membuat siswa merasa jenuh dan bosan serta tidak mendapatkan ilmu yang cukup banyak karena sumber ilmu hanya diperoleh dari guru dan buku panduan belajar saja. Fakta lain yang juga diperoleh adalah guru juga belum memanfaatkan fasilitas media pembelajaran yang disediakan sekolah guna menunjang proses pembelajaran. Hal itu dikarenakan kurangnya keterampilan guru dalam memanfaatkan fasilitas tersebut sehingga guru kurang update mengenai media pembelajaran seperti software GeoGebra. Padahal aplikasi software GeoGebra ini dapat digunakan untuk mendorong tercapainya tujuan pembelajaran dan membuat alokasi waktu lebih efisien. Sehingga dapat mengatasi masalah kekurangan alokasi waktu yang disebabkan karena banyaknya kegiatan yang dilaksanakan selama ini yang sering dialami guru pada proses pembelajaran matematika.

Cartesius: Jurnal Pendidikan Matematika Vol. 2, No. 2

CProdi Pendidikan Matematika Universitas Katolik Santo Thomas 
Dengan menggunakan aplikasi GeoGebra pembelajaran akan lebih menarik perhatian siswa, sehingga siswa dapat berperan aktif dalam pembelajaran matematika, hal ini dikarenakan materi yang disajikan selain menggunakan animasi terdapat penggunaan GeoGebra yang memiliki kelebihan dalam hal melukis gambar geometri. Proses pembelajaran ini merupakan hal penting yang akan dilihat guru sebagai bentuk pencapaian tujuan pembelajaran. Guru dituntut harus lebih kreatif dalam setiap pembelajaran dan mampu mempersiapkan serta melaksanakan kegiatan pembelajaran dengan benar dan matang. Guru juga harus mampu memanfaatkan sumber belajar dan berbagai jenis media pembelajaran yang sesuai agar proses pembelajaran dapat berjalan efektif dan efisien.Untuk memudahkan kegiatan tersebut, maka guru dapat memfasilitasi bahan ajar, salah satunya adalah dengan Lembar Kerja Siswa (LKS).

Dimana banyak siswa yang berpendapat bahwa matematika adalah ilmu yang sulit dipelajari, sehingga siswa mengalami banyak kesulitan pada saat mengikuti pelajaran matematika tersebut karena LKS yang digunakan kebanyakan kurang menarik dan hanya berisi rangkuman materi dan kumpulan soal-soal yang membuat siswa merasa cepat bosan dan tidak tertarik dalam pembelajaran matematika. Untuk mengatasi kesulitankesulitan yang dialami oleh siswa dalam mengikuti proses pembelajaran matematika, maka perlu adanya pengembangan bahan ajar untuk menunjang tercapainya keberhasilan siswa dalam pelajaran matematika terkait hasil belajar siswa disekolah.

LKS merupakan sebuah sarana pembelajaran yang digunakan guru dengan tujuan untuk meningkatkan keterlibatan atau aktivitas siswa dalam proses belajar-mengajar. Berdasarkan uraian tersebut, maka LKS dapat dilakukan sebagai pedoman siswa dalam melakukan kegiatan pembelajaran secara aktif dan membantu mengarahkan siswa untuk mengkonstruk pengetahuan yang telah dipelajari untuk menyelesaikan suatu masalah matematika. Agar Lembar Kerja Siswa (LKS) lebih menarik dan sesuai dengan karakteristik siswa, maka seharusnya LKS dibuat sendiri oleh guru. Sehingga dapat memudahkan siswa dalam memahami materi yang diberikan oleh guru pada proses pembelajaran.

Cartesius: Jurnal Pendidikan Matematika Vol. 2, No. 2

CProdi Pendidikan Matematika Universitas Katolik Santo Thomas 
Materi yang akan dikembangkan dalam Lembar Kerja Siswa (LKS) ini adalah bangun datar segiempat. Materi tersebut sangat berkaitan dengan kehidupan sehari-hari. Kebanyakan LKS pokok bahasan bangun datar segiempat yang digunakan siswa hanya berupa mencari penyelesaian masalah dan mengenal konsep bangun datar segiempat saja. Padahal LKS yang dimaksud belum tentu sesuai dengan tujuan pembelajaran yang ingin dicapai. Apalagi dengan tampilan LKS yang kurang menarik serta gaya bahasa yang sulit untuk dimengerti oleh siswa sehingga siswa tidak terlibat langsung dalam penemuan konsep untuk mengkonstruksi pengetahuannya sendiri.

Akibatnya, siswa hanya langsung menerima informasi dari LKS tanpa berusaha untuk mengeksplorasi kemampuannya untuk dapat memperoleh suatu informasi, serta mengakibatkan siswa lebih cenderung menghapalkan rumus yang ada yang berpengaruh pada kemampuan siswa dalam menyelesaikan suatu permasalahan matematika. Hal ini merupakan kekurangan dari LKS yang dijadikan bahan ajar dalam pembelajaran.

Pada saat ini sudah banyak sekali model LKS matematika yang telah dirancang guru. Namun sejalan dengan kurikulum yang berubah, pengembangan LKS disesuaikan dengan karakteristik siswa dan pendekatan pembelajaran yang dipilih guru. Salah satu jenis pendekatan pembelajaran adalah Contextual Teaching And Learning (CTL). PendekatanCTL sebagai salah satu pendekatan yang dapat digunakan dalam pembelajaran yang dapat membantu guru untuk mengembangkan LKS matematika. Guru dapat memodifikasi atau merancang LKS matematika yang lama dengan mengubah beberapa komponen yang ada pada CTL. Pendekatan ini mempunyai ciri yang biasa dikenal dengan tujuh komponen CTL, yaitu : 1) Construktivisme, 2) Inquiry, 3) Questioning, 4) Learning Community, 5) Modelling, 6) Reflection, 7) Authentic Assesment". Pendekatan CTL ini dapat membantu guru untuk menyusun perencanaan pembelajaran sesuai dengan tujuh komponen dan dapat digunakan sebagai bahan ajar yang menfasilitasi siswa untuk mengkonstruk pengetahuan.

Matematika merupakan salah satu mata pelajaran yang memiliki peranan penting dalam kelangsungan kehidupan manusia yang mengaitkan beberapa konsep yang saling berhubungan. Untuk itu perlu adanya pengembangan LKS guna menciptakan proses pembelajaran yang berarti

Cartesius: Jurnal Pendidikan Matematika Vol. 2, No. 2

CProdi Pendidikan Matematika Universitas Katolik Santo Thomas 
dan sesuai dengan ketentuan dalam Kurikulum 2013. Pengembangan LKS matematika berbasis pendekatan Contextual Teaching and Learning (CTL) dapat menjadi suatu alternatif. Hal ini akan memberikan kesempatan pada siswa untuk mengkonstruk pengetahuan dengan melakukan kegiatan berpikir yang aktif. Berdasarkan pemaparan di atas, maka peneliti tertarik untuk melakukan suatu penelitian yang berjudul "Pengembangan Lembar Kerja Siswa Berbasis Pendekatan Contextual Teaching and Learning (CTL) dengan bantuan GeoGebra Pada Materi Bangun Datar Segiempat Kelas VII SMP Swasta GKPI Padang Bulan Medan Tahun Ajaran 2018/2019".

\section{METODE}

Pendekatan penelitian yang dilakukan oleh peneliti yaitu pendekatan campuran kualitatif dan kuantitatif. Metode penelitian yang dilakukan adalah metode penelitian dan pengembangan atau Research and Development (R\&D). Metode ini digunakan untuk menghasilkan suatu produk tertentu dengan tujuan untuk mengembangkan LKS matematika yang valid dan efektif berbasis Pendekatan Contextual Teaching and Learning (CTL) dengan bantuan GeoGebra. Penelitian ini akan dilakukan di SMP Swasta GKPI Padang Bulan Medan kelas VII semester genap pada tahun ajaran 2018/2019. Alasan Peneliti memilih sekolah ini sebagai tempat penelitian, karena belum tersedianya Lembar Kerja Siswa (LKS) matematika dengan pendekatan berbasis Contextual Teaching and Learning (CTL) berbantuan GeoGebra sehingga pembelajaran berbasis $C T L$ ini belum dikenal baik oleh guru matematika disekolah tersebut.

Populasi penelitian ini adalah siswa SMP Swasta GKPI Padang Bulan Medan kelas VII-I Tahun Ajaran 2018/2019 terdiri dari 27 orang siswa. Model pengembangan yang diterapkan adalah model pengembangan ADDIE. Secara visual tahapan model ADDIE dapat dilihat pada bagan berikut :

Cartesius: Jurnal Pendidikan Matematika Vol. 2, No. 2

CProdi Pendidikan Matematika Universitas Katolik Santo Thomas 


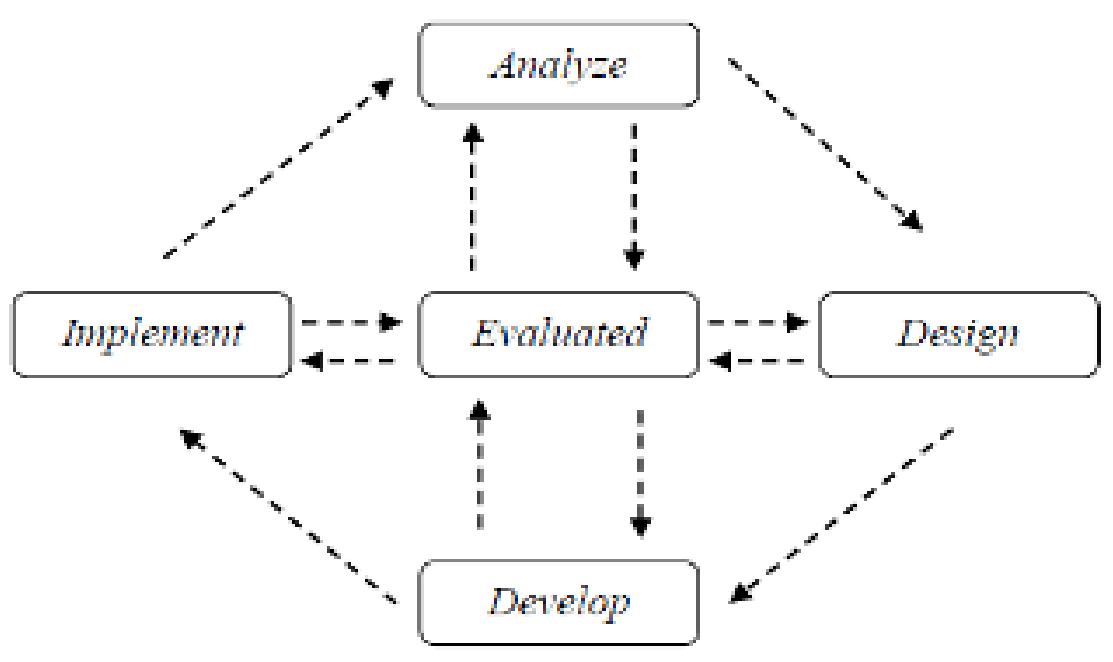

Gambar 1. Tahap Pengembangan Produk Model ADDIE

Jenis data yang digunakan dalam penelitian ini adalah data kualitatif dan kuantitatif. Data kualitatif berupa hasil penilaian ahli, hasil lembar observasi kemampuan mengelola pembelajaran dan angket respon siswa. Data kuantitatif berupa nilai hasil belajar siswa melalui perangkat pembelajaran yang dikembangkan yaitu LKS. Sumber data penelitian diperoleh dari angket dan hasil belajar siswa. Teknik yang digunakan adalah purposive sampling. Hal ini dilakukan karena peneliti memilih sekolah yang menerapkan Kurikulum 2013 dalam kegiatan pembelajaran dan sampel siswa yang terpilih untuk diteliti adalah siswa kelas VII SMP Swasta GKPI Padang Bulan Medan.Teknik yang digunakan dalam penelitian ini adalah tes dan non-tes yang dimaksud yaitu berupa soal tes akhir berbentuk soal uraian dan tes hasil belajar. Selanjutnya, non-tes yang dimaksud pada penelitian ini adalah berupa angket kemampuan mengelola kelas serta angket respon siswa. Alat yang digunakan dalam penelitian ini pada pengembangan perangkat pembelajaran yaitu lembar validasi (RPP, tes hasil belajar, dan LKS), data hasil belajar siswa, kemampuan guru mengelola pembelajaran, dan angket respon siswa.

\subsection{Analisis Data Hasil Validasi Ahli}

Kevalidan perangkat pembelajaran diperoleh dari hasil analisis data lembar penilaian perangkat pembelajaran oleh validator. Analisis kevalidan dilakukan sebagai berikut:

a. Tabulasi data skor hasil penilaian perangkat pembelajaran dengan

Cartesius: Jurnal Pendidikan Matematika Vol. 2, No. 2

CProdi Pendidikan Matematika Universitas Katolik Santo Thomas 
mengelompokkan butir-butir pertanyaan yang sesuai dengan aspekaspek yang diamati.

Tabel 1. Pedoman Penskoran terhadap Hasil Penilaian

\begin{tabular}{lc}
\hline Kriteria & Skor \\
\hline Sangat Baik & 5 \\
Baik & 4 \\
Cukup & 3 \\
Kurang & 2 \\
Sangat Kurang & 1 \\
\hline
\end{tabular}

b. Menghitung rata-rata skor tiap aspek dengan menggunakan rumus:

$$
\bar{x}=\frac{\Sigma_{i-n}^{n} x i}{n}
$$

Keterangan:

$\bar{x}=$ Rerata skor

$x_{i}=$ Skor keterangan ke- $\mathrm{i}$

$\mathrm{n}$ = Banyaknya butir pertanyaan tiap aspek

Skor maksimal ideal adalah 5 dan skor minimal ideal adalah 1, maka diperoleh klasifikasi penilaian perangkat pembelajaran ditunjukkan pada tabel 2 berikut:

Tabel 2. Pedoman Kriteria Kevalidan

\begin{tabular}{cc}
\hline Interval Skor & Kriteria \\
\hline $\bar{x}>4,2$ & Sangat Baik \\
$3,4<\bar{x} \leq 4,2$ & Baik \\
$2,6<\bar{x} \leq 3,4$ & Cukup \\
$1,8<\bar{x} \leq 2,6$ & Kurang \\
$\bar{x} \leq 1,8$ & Sangat Kurang \\
\hline
\end{tabular}

Berdasarkan tabel 2 akan diperoleh kualifikasi kevalidan perangkat pembelajaran yang dikembangkan. Perangkat pembelajaran dikatakan valid jika minimal kualifikasi tingkat kevalidan yang diperoleh adalah baik.

\subsection{Analisis Keefektifan LKS}

\section{a. Ketuntasan Belajar Klasikal Siswa}

Untuk menghitung ketuntasan belajar klasikal dapat digunakan rumus :

Cartesius: Jurnal Pendidikan Matematika Vol. 2, No. 2

CProdi Pendidikan Matematika Universitas Katolik Santo Thomas 


$$
\mathrm{PKK}=\frac{\mathrm{T}}{\mathrm{T}_{\mathrm{t}}} \times 100 \%
$$

Keterangan:

PKK $=$ Ketuntasan Klasik

$\mathrm{T}=$ jumlah siswa yang tuntas

$\mathrm{T}_{\mathrm{t}}=$ jumlah siswa total

\section{b. Ketercapaian Indikator}

Untuk menghitung pencapaian indikator dalam pembelajaran digunakan rumus:

$$
\mathrm{T}=\frac{\mathrm{S}_{i}}{\mathrm{~S}_{\text {maks }}} \times 100 \%
$$

Keterangan:

$\mathrm{T}=$ persentase pencapaian indikator

$\mathrm{S}_{i} \quad$ = jumlah skor siswa untuk butir soal ke-i

$\mathrm{S}_{\text {maks }}=$ jumlah skor maksimal untuk butir soal ke-i

Dengan kriteria :

$$
\begin{aligned}
0 \% & \leq \mathrm{T}<75 \% \mathrm{TPK} \text { belum tercapai } \\
75 \% & \leq \mathrm{T}<100 \% \mathrm{TPK} \text { tercapai }
\end{aligned}
$$

\section{c. Kemampuan Guru Mengelola Pembelajaran}

Data hasil penelitian kemampuan guru mengelola pembelajaran dengan pendekatan berbasis CTL dengan mencari rata-rata nilai kemampuan guru mengelola pembelajaran dari empat kali pembelajaran dan efektif jika mencapai kategori cukup baik. Kriteria tingkat kemampuan guru (TKG) mengelola pembelajaran (Hasratuddin,2002:48) adalah :

$$
\begin{aligned}
& 1,00 \leq \text { TKG } \leq 1,49 \text { adalah tidak baik } \\
& 1,50 \leq \text { TKG } \leq 2,49 \text { adalah kurang baik } \\
& 2,50 \leq \text { TKG } \leq 3,49 \text { adalah cukup baik } \\
& 3,50 \leq \text { TKG } \leq 4,00 \text { adalah sangat baik }
\end{aligned}
$$

\section{d. Waktu Pembelajaran}

Waktu pembelajaran yang selama uji coba yaitu tidak lebih atau sama dengan waktu pembelajaran biasa.

Cartesius: Jurnal Pendidikan Matematika Vol. 2, No. 2

CProdi Pendidikan Matematika Universitas Katolik Santo Thomas 


\section{e. Angket Respon Siswa}

Analisis angket respon siswa dapat dilakukan dengan cara berikut:

1) Tabulasi data skor hasil angket respon siswa dengan mengelompokkan butir-butir pernyataan sesuai dengan aspek-aspek yang diamati.

Tabel 3. Pedoman Penskoran Angket Respon Siswa

\begin{tabular}{lcc}
\hline \multirow{2}{*}{ Kategori } & \multicolumn{2}{c}{ Skor Pernyataan } \\
& Positif & Negatif \\
\hline Sangat Setuju (SS) & 5 & 1 \\
Setuju (S) & 4 & 2 \\
Netral (N) & 3 & 3 \\
Tidak Setuju (TS) & 2 & 4 \\
Sangat Tidak Setuju (STS) & 1 & 5 \\
\hline
\end{tabular}

2) Menghitung rata-rata skor tiap aspek dengan menggunakan formula :

$$
\bar{x}=\frac{\sum_{n=1}^{n} x_{i}}{n}
$$

Keterangan :

$\bar{x}=$ rerata skor

$x_{i}=$ skor ke-i

$n$ = banyaknya butir pernyataan tiap aspek

3) Mengkonversi skor rerata setiap aspek penilaian menjadi nilai kualitatif berdasarkan kriteria penilaian skala 5 menurut Widoyoko (2009:238) seperti yang tercantum pada tabel 2 sebelumnya, sehingga diperoleh kualifikasi perangkat pembelajaran yaitu LKS yang telah dikembangkan berdasarkan tabel 3 di atas. Perangkat pembelajaran dikatakan efektif jika minimal kualifikasi angket respon siswa yang diperoleh adalah baik ataupun sangat baik.

\section{HASIL DAN PEMBAHASAN}

Data-data hasil analisis penelitian menunjukkan bahwa ketuntasan belajar secara klasikal mencapai $85,18 \%$ persentase ketercapaian indikator sebesar $83,14 \%$ nilai rata-rata kemampuan guru mengelola pembelajaran sebesar 3,72 dengan kategori Sangat Baik, waktu pembelajaran efektif serta persentase angket respon siswa yang positif sebesar 5,50. Oleh karena itu, LKS

Cartesius: Jurnal Pendidikan Matematika Vol. 2, No. 2

CProdi Pendidikan Matematika Universitas Katolik Santo Thomas 
matematika yang dikembangkan berbasis pendekatan Contextual Teaching And Learning (CTL) dengan bantuan GeoGebra Pada Materi Bangun Datar Segiempat di SMP kelas VII yang telah dikembangkan dapat dikatakan valid dan efektif.

\section{KESIMPULAN}

Berdasarkan analisis data hasil penelitian dan pembahasan, maka dapat disimpulkan bahwa:

1. Kevalidatan LKS yang diperoleh berdasarkan hasil lembar validasi oleh validator dengan beberapa saran serta perbaikan menunjukkan bahwa LKS beserta instrumen penelitian lainnya yang dikembangkan berbasis pendekatan Contextual Teaching and Learning (CTL) dengan bantuan GeoGebra pada materi Bangun Datar Segiempat di kelas VII-2 SMP Swasta GKPI Padang Bulan Medan adalah valid dengan rata-rata total penilaian 4,25 dan hasil validasi LKS adalah "Sangat Baik" sehingga layak digunakan untuk penelitian dilapangan.

2. Keefektifitan bahan ajar berupa LKS yang dikembangkan melalui pendekatan Contextual Teaching And Learning (CTL) dengan bantuan GeoGebra pada materi bangun datar segiempat kelas VII SMP diperoleh melalui uji coba di lapangan. Pada uji coba, LKS yang dikembangkan telah memenuhi kriteria efektif yang ditunjukkan dengan hasil, yaitu (1) Ketuntasan belajar siswa secara klasikal terpenuhi sebesar 85,18\%, (2) Ketercapaian indikator pencapaian kompetensi sebesar 83,14\%, (3) Kemampuan guru dalam mengelola pembelajaran efektif dengan nilai rata-rata keseluruhan kategori adalah 3,72, (4) Waktu pembelajaran yang digunakan pada saat uji coba adalah 4 kali pertemuan efektif selama 8 x 40 menit serta (5) Angket respon siswa yang positif untuk setiap aspek terhadap LKS dengan rata-rata penilaian sebesar 5,50 dan masuk ke dalam kategori positif. Setelah semua kriteria keefektifan terpenuhi maka dapat disimpulkan bahwa LKS yang telah dikembangkan melalui pendekatan Contextual Teaching And Learning (CTL) dengan bantuan GeoGebra pada materi Bangun Datar Segiempat kelas VII SMP telah efektif digunakan.

Cartesius: Jurnal Pendidikan Matematika Vol. 2, No. 2

CProdi Pendidikan Matematika Universitas Katolik Santo Thomas 


\section{UCAPAN TERIMAKASIH}

Penulis menyampaikan terima kasih kepada Ibu Ribka Kariani Sembiring, S.Si., M.Pd. sebagai Dosen Pembimbing 1 dan Ibu Sinta Dameria Simanjuntak, S.Si., M.Pd. sebagai Dosen Pembimbing 2 yang telah mengarahkan dan membimbing penulis mulai dari awal penelitian hingga berakhirnya penelitian sehingga penulis dapat menuliskan artikel ini yang merupakan bagian dari hasil penelitian penulis.

\section{DAFTAR PUSTAKA}

[1] Arikunto Suharsimi, 2013. Dasar-Dasar Evaluasi Pendidikan. Edisi Kedua 2013. Jakarta: Bumi Aksara.

[2] Arifin, 2017. "Penerapan Model Penemuan Terbimbing Pada Lesson Study Pembelajaran Materi Transformasi Berbantuan GeoGebra". Jurnal Program Studi Pendidikan Matematika, Volume 3 No. 2.

[3] Aminah Ekawati, 2016. "Pengembangan Software GeoGebra dan MicrosoftMathematic Dalam Pembelajaran Matematika". Jurnal Matematika Vol.2, No.3. ISSN 2442-3041.

[4] Aspia, Daulay, 2013. Media Pembelajaran. Medan: Perdana Publishing.

[5] Bambang Sadiyono, 2014. "Pendekatan Contextual Teaching and Learning Untuk Meningkatkan Prestasi Belajar Pada Bidang Matematika". Jurnal Pendidikan Matematika, Volume 3 No.2 , Mei 2014.

[6] Eggen. P, Kauchak.D, 2012. Strategi dan Model Pembelajaran. Edisi Keenam 2012. Jakarta: PT Indeks.

[7] Emzir, 2008. Metodologi Penelitian Pendidikan: Kuantitatif dan Kualitatif. Jakarta: Rajawali Pers.

[8] Jejen Musfah, 2017. Manajemen Pendidikan. Jakarta : Kencana.

[9] Khasanah, Ainun \& Sunarti. T , 2016. "Pengembangan Lembar Kerja Siswa (LKS) menggunakan Model ADDIE pada Materi Gerak Lurus di MAN Surabaya". Jurnal Inovasi Pendidikan Fisika, 45-48.

[10]Kemendikbud.(2014). Buku Guru Matematika SMP/MTS Kelas VIII. Kemendikbud: Jakarta.

[11]Kunandar, S,Pd., M.Si. Guru Profesional. Edisi Revisi. Jakarta: Kencana.

[12]Lussy Midani Rizki, Risnawati \& Zubaidah. 2017. "Pengembangan Lembar Kerja Siswa Berbasis Pendekatan Contextual Teaching and Learning Untuk Memfasilitasi Kemampuan Koneksi Siswa SMP/MTS". Indonesian Digital

Cartesius: Jurnal Pendidikan Matematika Vol. 2, No. 2

CProdi Pendidikan Matematika Universitas Katolik Santo Thomas 
Journal Of Mathematics and Education, Volume 4 Nomor 6 Tahun 2017. ISSN 2407-8530.

[13]Ni Wayan Suardiati, Suriyasa \& I Made Ardana. 2014. "Pengembangan

Perangkat Pembelajaran Berbantuan GeoGebra Sebagai Upaya Meningkatkan Prestasi dan Aktivitas Belajar Geometri Siswa". e-Journal Program Pascasarjana Universitas Pendidikan Ganesha. Program Studi Matematika,Volume 02 Nomor 02.

[14]Nunung Novisa, 2014. Pengembangan Lembar Kerja Siswa Matematika Berbasis Pendekatan Contextual Teaching And Learning (CTL) Pada pokok Bahasan Aritmetika Sosial di SMP Negeri 1 Kota Bengkulu. Skripsi Jurusan Pendidikan Matematika FPMIPA.

[15]Rini Wulandari, 2015. Pengembangan Media Pembelajaran Matematika Interaktif Berbantuan GeoGebra Melalui Pendekatan Saintifik Berbasis Penemuan Terbimbing (Guided Discovery) Pada Materi Persamaan Lingkaran Untuk Siswa SMA Kelas XI. Skripsi Jurusan Pendidikan Matematika FMIPA.

[16]Rusman, 2013. Model-model Pembelajaran Mengembangkan Profesional Guru Edisi kedua 2013. Jakarta: PT Raja Grafindo Persada.

[17]Sanjaya. W, 2008. Perencanaan dan Desain Sistem Pembelajaran. Edisi Pertama 2008. Bandung: Kencana Prenamedia Group.

[18]Sanjaya. W, 2012. Media Komunikasi Pembelajaran. Edisi Pertama 2012. Jakarta: Kencana Prenamedia Group.

[19]Silberman. M, 2010. 101 Cara Pelatihan dan Pembelajaran Aktif. Edisi Pertama 2010. Jakarta Barat: PT Indeks.

[20]Sudijono Anas, 2013. Pengantar Evaluasi Pendidikan. Jakarta: PT Raja Grafindo Persada.

[21]Sudjana, 2002. Metoda Statistika. Edisi Keenam 2002. Bandung: Tarsito. [22]Sugiyono, 2015. Metode Penelitian Kuantitatif, Kualitatif dan RED. Bandung: Alfabeta.

[23]Sumaryanta, 2015. Pedoman Penskoran. Indonesian Digital Journal of Mathematics and Education,Vol. 2 No. 3 Tahun 2015. ISSN 2407-7925. [24]Suprijono, Agus. 2010. Cooperativ Learning. Yogyakarta: Pustaka Belajar.

[25]Sundayana Rostina, 2014. Statistika Penelitian Pendidikan. Bandung: Alfabeta.

[26]Uno B. Hamzah, 2017. Model Pembelajaran Menciptakan Proses Belajar Mengajar yang Kreatif dan Efektif. Jakarta: Bumi Aksara.

Cartesius: Jurnal Pendidikan Matematika Vol. 2, No. 2

CProdi Pendidikan Matematika Universitas Katolik Santo Thomas 
[27]Yansa Hajra, 2017. Efektivitas Pembelajaran Matematika Melalui Model Kooperatif Tipe Make A Match pada Siswa Kelas X IPA SMA Negeri 1 Gowa. Jurnal Pena: Volume 03 Nomor 01.

[28]Yulia dan Nencita O. Sunggu. Efektivitas Model Pembelajaran Contextual Teaching and Learning (CTL) Terhadap Kemampuan Pemecahan Masalah Matematis Siswa Kelas VIII SMP N 16 Batam Tahun Pelajaran 2014/2015. Jurnal Pythagoras, Volume 5, Nomor 1, April 2016. ISSN: 201-5314. 